\title{
Diagrammatic scale for the assessment of blast on wheat spikes
}

\author{
João Leodato Nunes Maciel ${ }^{1}$, Anderson Luiz Durante Danelli ${ }^{2}$, Cristina Boaretto ${ }^{3}$, Carlos Alberto Forcelini ${ }^{3}$
}

${ }^{1}$ Embrapa Trigo, Rod. BR-285, Km 294, 99001-70, Passo Fundo, RS, Brazil; ${ }^{2}$ Programa de Pós-Graduação em Agronomia - PPGAgro, Universidade de Passo Fundo, 99001-970, Passo Fundo, RS, Brazil; ${ }^{2}$ Bolsista Capes/Prosup/UPF. ${ }^{3}$ Faculdade de Agronomia e Medicina Veterinária, Universidade de Passo Fundo, 99001-970, Passo Fundo, RS, Brazil.

Autor pra correspondência: João Leodato Nunes Maciel (joao.nunes-maciel@embrapa.br)

Data de chegada: 01/04/2013. Aceito para publicação em: 16/07/2013.

ABSTRACT

Maciel, J.L.N.; Danelli, A.L.D.; Boretto, C.; Forcelini, C.A. Diagrammatic scale for assessment of blast on wheat spikes. Summa Phytopathologica, v.39, n.3, p.162-166, 2013.

The correct quantification of blast caused by the fungus Magnaporthe oryzae on wheat (Triticum aestivum) spikes is an important component to understand the development of this disease aimed at its control. Visual quantification based on a diagrammatic scale can be a practical and efficient strategy that has already proven to be useful against several plant pathosystems, including diseases affecting wheat spikes like glume blotch and fusarium head blight. Spikes showing different disease severity values were collected from a wheat field with the aim of elaborating a diagrammatic scale to quantify blast severity on wheat spikes. The spikes were photographed and blast severity was determined by using resources of the software ImageJ. A diagrammatic scale was developed with the following disease severity values: $3.7,7.5,21.4,30.5,43.8,57.3,68.1$, 86.0 , and $100.0 \%$. An asymptomatic spike was added to the scale. Scale validation was performed by eight people who estimated blast severity by using digitalized images of 40 wheat spikes. The precision and the accuracy of the evaluations varied according to the rater $\left(0.82<\mathrm{R}^{2}<0.90\right.$, $-6.12<\mathrm{a}<2.94,0.85<\mathrm{b}<1.16)$, and systematic errors in overestimating or underestimating the disease were not found among the raters, demonstrating that the developed scale is suitable to evaluate blast on wheat spikes.

Additional keywords: Magnaporthe oryzae, Pyricularia grisea, ImageJ, severity, epidemic.

\section{RESUMO}

Maciel, J.L.N.; Danelli, A.L.D.; Boretto, C.; Forcelini, C.A. Escala diagramática para avaliação de brusone na espiga de trigo. Summa Phytopathologica, v.39, n.3, p.162-166, 2013.

A quantificação correta da brusone causada pelo fungo Magnaporthe oryzae em espigas de trigo (Triticum aestivum) é um componente importante para o entendimento do desenvolvimento dessa doença com vistas ao seu controle. A quantificação visual baseada em uma escala diagramática pode ser uma tarefa prática e eficiente que já tem demonstrado utilidade em diversos patossistemas, inclusive doenças da espiga do trigo como a mancha das glumas e fusariose. Espigas apresentando diferentes valores de severidade da doença foram coletadas em uma lavoura com o objetivo de elaborar uma escala diagramática para quantificar a severidade da brusone em espigas de trigo. As espigas foram fotografadas e a severidade da brusone foi determinada usando os recursos do programa computacional ImageJ. Uma escala diagramática foi elaborada com os seguintes valores de severidade de doença: 3,$7 ; 7,5 ; 21,4 ; 30,5 ; 43,8 ; 57,3 ; 68,1 ; 86,0$; e $100,0 \%$. Uma espiga assintomática foi adicionada à escala. A validação da escala foi realizada por oito pessoas que estimaram a severidade da brusone em imagens digitalizadas de 40 espigas de trigo. A precisão e a acurácia das avaliações variaram de acordo com o avaliador $\left(0,82<\mathrm{R}^{2}<0,90 ;-6,12<\mathrm{a}<2,94 ; 0,85<\mathrm{b}<1,16\right)$, não ocorrendo erro sistemático na superestimativa ou subestimativa da doença entre os avaliadores, demonstrando que a escala desenvolvida é adequada para a avaliação da brusone em espigas de trigo.

Palavras-chave adicionais: Magnaporthe oryzae, Pyricularia grisea, ImageJ, severidade, epidemia.

Blast caused by the fungus Magnaporthe oryzae B. Couch (Pyricularia oryzae anamorph. dig) is one of the major limits to food production in the world, affecting several crops of agricultural importance. For South America, since the mid-1980s, when it was first reported to affect wheat plants, this disease has also been characterized as one of the most serious problems for wheat crops, especially in Brazil, Bolivia and Paraguay $(5,10,12)$. Difficulties for its control are enormous. Management practices such as crop rotation, balanced fertilization and treatment of aerial parts with fungicides are not sufficient to prevent the economic damage caused by this disease, especially in seasons of severe epidemics $(6,7,13)$.
An important problem in Brazilian wheat fields is that the cultivars available to the producers are susceptible to blast, which demonstrates that the development of cultivars with higher resistance is an indispensable component of the strategy to control this disease. Improving the process for evaluating the reaction of genotypes to the disease is also part of this strategy. Thus, an additional difficulty is the lack of a diagrammatic scale to help evaluate the disease severity on spikes. Other fungal diseases of importance to the wheat crop have had this type of tool available for a long time, for example, fusarium head blight, caused by Gibberella zeae, which also infects wheat spikes $(8,11,18,19,21,22)$. 
The quantification of a disease is a fundamental step for understanding its development and implementing strategies to manage it (1). Besides, its importance is not limited as a strategy used in the comparison of genotypes for their resistance to a disease in a breeding program. The degree of development of a fungal disease, quantified with the aid of a diagrammatic scale, may be related to the damage caused by this disease in a crop or even to the efficiency of a certain treatment, such as spraying of a fungicide for its control. However, some characteristics are essential for a diagrammatic scale to be considered efficient. Among these features are: easy use, wide applicability, reproducible results, and intervals that represent all stages of the disease development (4). Added to these aspects, Horsfal $\&$ Barrat (9) determined that the diagrammatic scales must have a sequence of severity values that satisfy the principle of logarithmic increment established in the "law of Weber-Fechner." According to this proposition, perception intensity measures of the five senses of humans, in which vision is included, are made in logarithmic magnitude.

The aim of this study was to develop a diagrammatic scale to determine the severity of blast caused by Magnaporthe oryzae on wheat spikes.

\section{MATERIALAND METHODS}

One hundred spikes with blast symptoms of cultivar BRS Pioneiro were collected from a wheat field located in Londrina, Paraná State (PR), in the 2012 Brazilian wheat season. The spikes were collected, placed in paper bags and taken to the Laboratory of Plant Pathology of Embrapa Wheat, located in Passo Fundo, Rio Grande do Sul State (RS), where they were kept at $-20^{\circ} \mathrm{C}$.

\section{Elaboration of the diagrammatic scale}

Photographs were taken of each group of five spikes, which were subjected to the following procedures. They were hydrated by immersion in a beaker with water for about $30 \mathrm{~min}$ and allowed to dry on a paper towel for about $10 \mathrm{~min}$. Subsequently, the spikes were placed on white papers, which were on a laboratory bench, with a ruler placed on the bottom or on the left side of the sheets. The spikes were positioned with the most symptomatic side in front of the camera. The images of the spikes were captured with a Sony Cybershot digital camera DSC/-H7/H9 (Sony, Brazil), which was manually held at approximately $50 \mathrm{~cm}$ above the spikes. Each image was compressed and saved as Joint Photographic Experts Group (JPEG) format as input for the ImageJ software (20), which was used to analyze the digital photographs. The unit used to measure the total, the healthy and the symptomatic area of the spikes was square centimeter $\left(\mathrm{cm}^{2}\right)$, which was established based on the calibration dimensions obtained from the ruler scale that was below or beside the spike. A binary pattern of colors was used to determine the total area of spikes, i.e., black color on white background.

The selection and the quantification of spike areas affected by the disease were performed based on the characteristics of the ImageJ software. The symptomatic regions were marked with the mouse cursor and the diseased spike area was calculated by subtracting the non-diseased spike area (also marked with the mouse cursor) from the total spike area. The awns on the images were separated and not considered spike areas. The ImageJ software was used under the following conditions: 8 bits/pixel, $0.1 \%$ saturation of pixels, all particles were considered ( 0 to infinity), and photosensitivity with $65 \%$ of noise tolerance (interference accepted by the program).
The severity levels used in the scale were selected by considering minimum and maximum limits for the diseased spikes in the wheat field in Londrina 0 (zero) and $100 \%$ blast severity, respectively. Intermediate levels were defined mathematically according to the logarithmic increase and as per the "law of the stimulus" established by Weber \& Fechner (9).

\section{Validation of the diagrammatic scale}

Eight people estimated blast severity in the digitalized images of 40 wheat spikes with the aid of the diagrammatic scale developed in the present study. Using the same procedures described above for the quantification of diseased areas affected by blast to elaborate the diagrammatic scale, the disease severity on 40 digitalized images of symptomatic spikes was determined (one spike per image). The accuracy and the precision of visual estimates of each rater were determined by linear regression analysis, considering the actual and the estimated severity as the independent and the dependent variable, respectively. The accuracy of each rater was determined by $t$ test applied to the linear (a) and angular (b) coefficients of the straight line obtained from the linear regression between the two above-mentioned variables. The precision of the estimates was assessed by determining the regression coefficient $\left(\mathrm{R}^{2}\right)$ and the variance of absolute errors (estimated severity minus actual severity) $(15,16)$.

\section{RESULTS AND DISCUSSION}

A cultivar with awns on the spikes (BRS Pioneiro) was chosen to elaborate the diagrammatic scale because most wheat cultivars used in Brazil have this characteristic. However, to obtain the severity values shown in the scale, the awns were not considered part of the spikes (Figure 1). This convention was used for both the scale elaboration

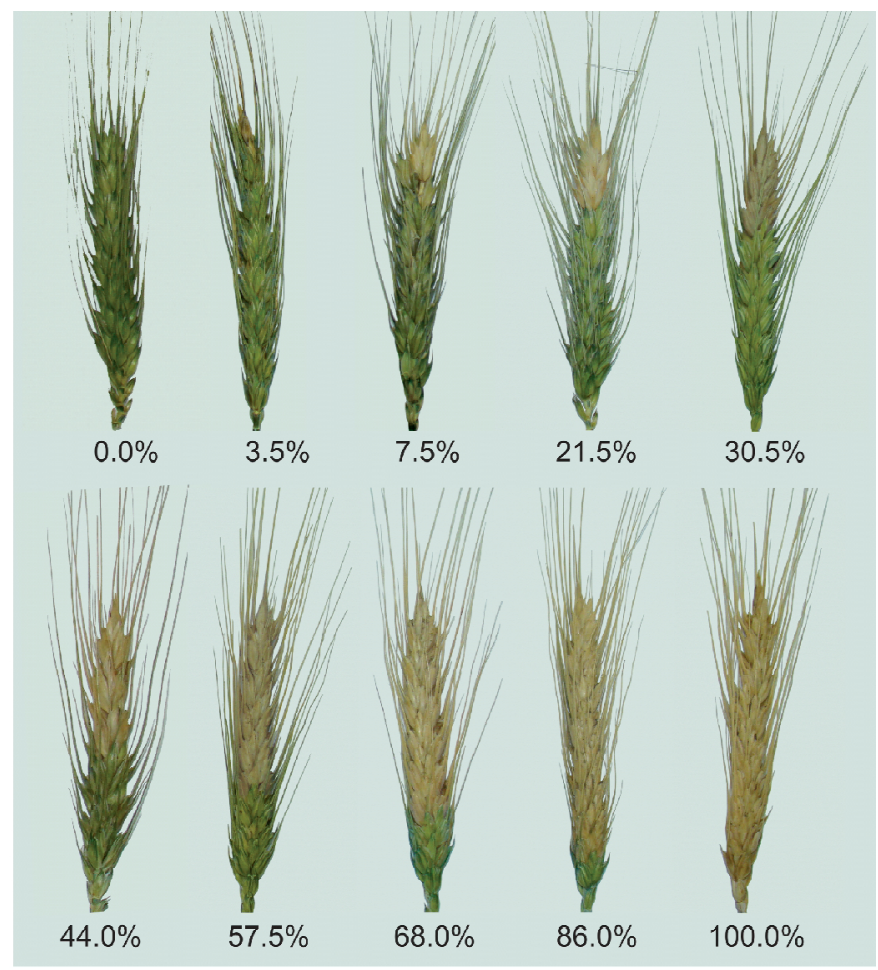

Figure 1. Diagrammatic scale for assessing blast severity caused by Magnaporthe oryzae on wheat spikes. The awns were not considered in the determination of severity on the spikes. 
and the validation procedures and was adopted by considering that, in general, the infection process caused by the fungus $M$. oryzae does not reach this segment of the spike.

Minimum and maximum blast severity levels found for the collected spikes were $3.7 \%$ and $100 \%$, respectively. These values were considered lower and upper limits, respectively, in relation to the symptomatic spikes of the diagrammatic scale (Figure 1). In total, 10 spikes formed the diagrammatic scale, one of which is asymptomatic ( $0 \%$ blast, i.e., the first one in the scale) and the other nine show different blast severity values.

The adopted sequence of severity values in the scale was proposed to meet the logarithmic increment principle established by WeberFechner. Based on this principle, Horsfall \& Barratt (9) suggested that the diagrammatic scales should have severity levels inserted in the following 12 intervals: $1(0), 2$ (0\%-3\%), $3(3 \%-6 \%), 4(6 \%-12 \%)$, 5 (12\%-25\%), 6 (25\%-50\%), 7 (50\%-75\%), 8 (75\%-88\% ), 9 (88\%94\%), 10 (94\%-97\%), 11 (97\%-100\%), and 12 (100\%). According to Campbell \& Madden, cited by Martins et al. (14), some authors have hesitated to use scales designed based on this principle mainly because there are only two severity level intervals ranging from $25 \%$ to $75 \%$. However, these intervals can be subdivided into shorter intervals, as proposed by Amorim et al. (2), Martins et al. (14), and in the present study. This means that the diagrammatic scale presented here followed the "law of Weber-Fechner" (logarithmic increments) without necessarily having used only one severity level of each interval suggested by Horsfall \& Barratt (9). This applies to spikes showing $30.5 \%$ and $43.8 \%$ severity, which belong to interval $6(25 \%-50 \%)$, as well as to spikes showing $57.3 \%$ and $68.1 \%$ severity, which belong to interval $7(50 \%-75 \%)$.

For most raters, the estimated severity values were close to the actual values (Figure 2). This assertion is based on the results obtained from the $t$ and $\mathrm{R}^{2}$ statistical tests, used for evaluating the linear regression between the two variables (Table 1). Such proximity between estimation and actuality determines the precision of assessments, defined as the accuracy without systematic errors which can be measured by the linear $(a)$ and angular $(b)$ coefficients of the linear regression established between the actual and estimated severity (3). The exception was rater 6 , for whom $a$ and $b$ values significantly differed from zero and one [1], respectively, according to $t$ test (Table 1). In the case, this rater underestimated blast severity in the spikes considering that the angular coefficient of the linear regression between the actual and the estimated severity was significantly lower than 1 .
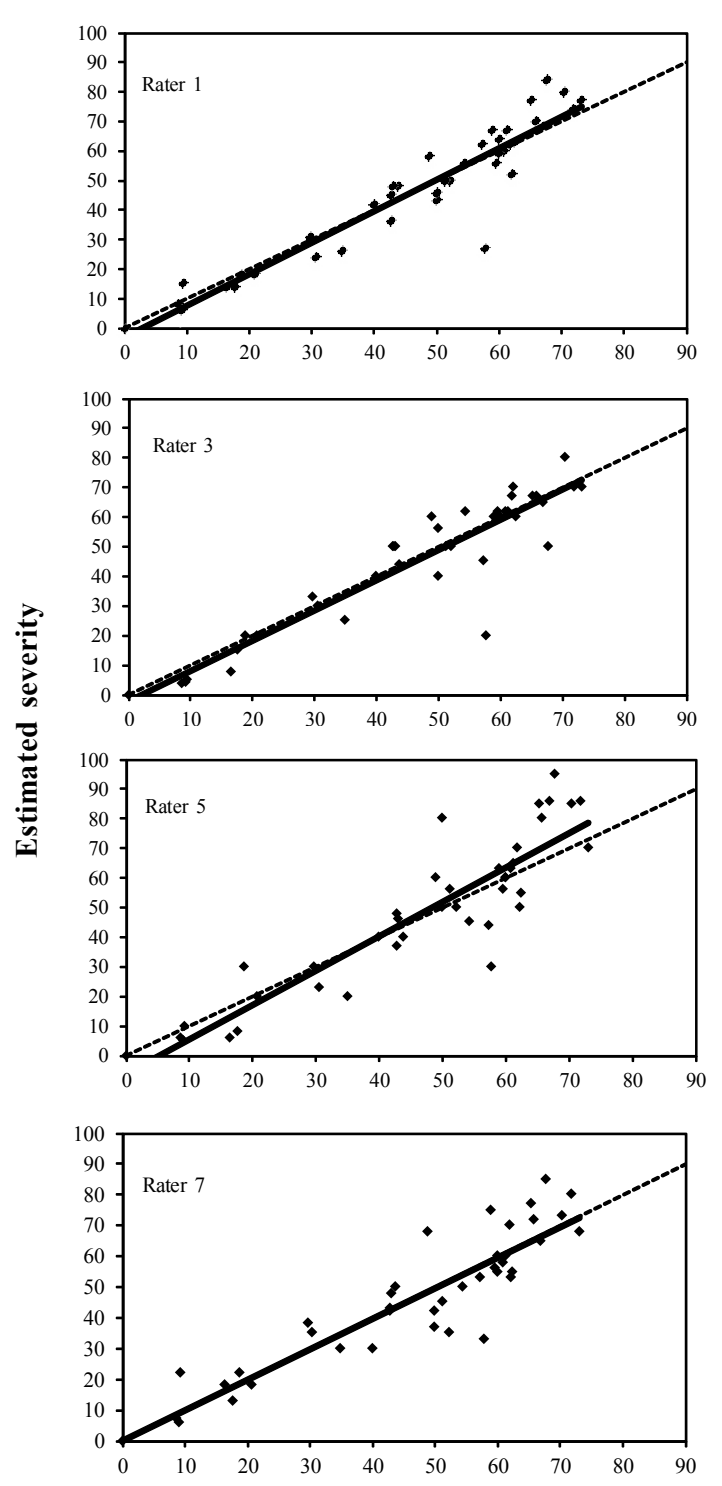
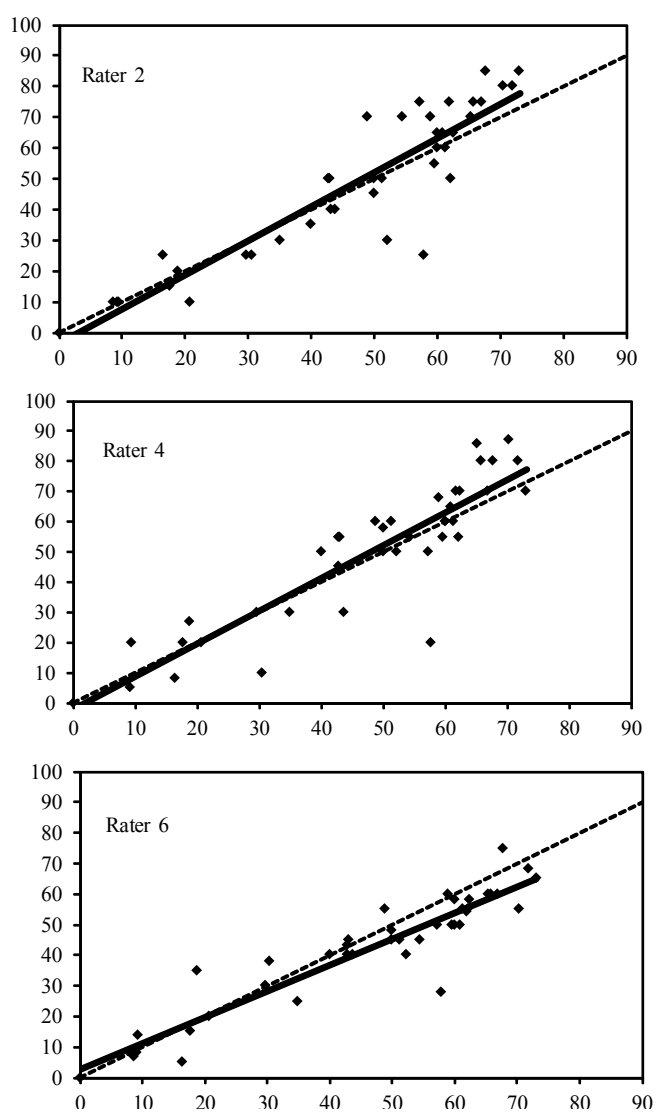

Figure 2. Estimated severity of wheat blast, caused by Magnaporthe oryzae, and linear regressions obtained between actual and estimated severity (solid line). Dotted lines represent an ideal situation, in which estimated severity is equal to actual severity.

Actual severity 
Table 1. Linear (a), angular (b) and determination $\left(\mathrm{R}^{2}\right)$ coefficients of the regression line for actual (independent variable) versus estimated severity (dependent variable) of blast, caused by Magnaporthe oryzae, on 40 wheat spikes evaluated by eight raters using the diagrammatic scale

\begin{tabular}{|c|c|c|c|c|c|c|c|c|}
\hline \multirow{2}{*}{ Coefficient } & \multicolumn{8}{|c|}{ Raters } \\
\hline & 1 & 2 & 3 & 4 & 5 & 6 & 7 & 8 \\
\hline $\mathrm{a}$ & -3.10 & -3.83 & 2.94 & 2.20 & -6.12 & $2.78 *$ & 0.18 & 0.64 \\
\hline $\mathrm{b}$ & 1.07 & 1.11 & 0.91 & 1.09 & 1.16 & $0.85 *$ & 0.99 & 1.00 \\
\hline $\mathrm{R}^{2}$ & 0.90 & 0.83 & 0.87 & 0.82 & 0.82 & 0.86 & 0.83 & 0.87 \\
\hline
\end{tabular}

*Hypotheses $\mathrm{a}=0$ and $\mathrm{b}=1$ were rejected according to $t$ test, at significance of 0.05 .

Precision can be evaluated based on the variation of absolute errors and on the $\mathrm{R}^{2}$ coefficient, obtained from regression analysis, which becomes more accurate as it gets closer to 1 . As regards the scale developed in this study, the evaluators had very good precision, with $\mathrm{R}^{2}$ ranging from 0.83 to 0.90 . Besides $\mathrm{R}^{2}$ coefficient, the good precision was confirmed when the difference between the actual and the estimated severity values was calculated, and the result was named absolute error or residue (Figure 3). Most of the absolute error values
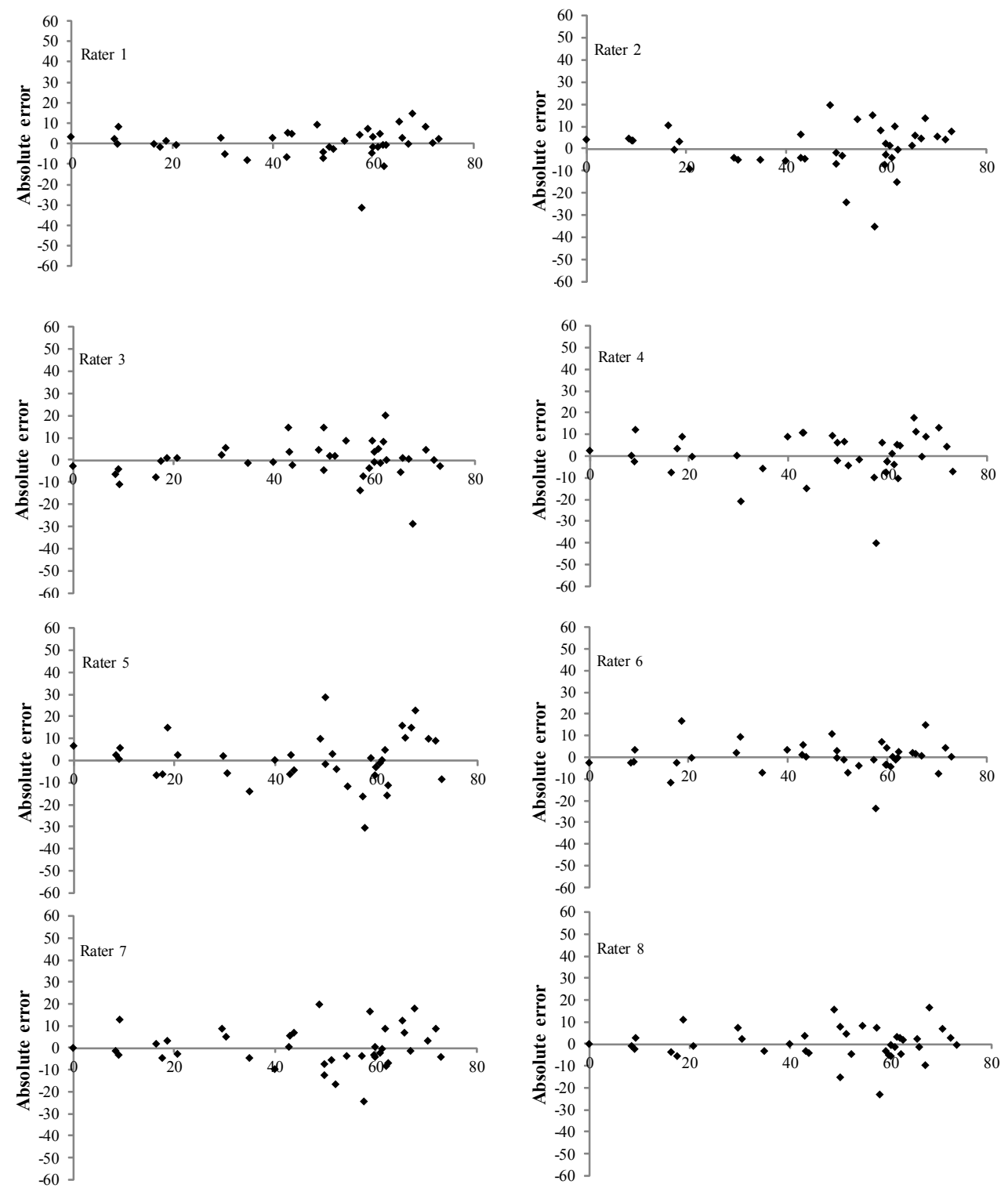

Actual severity did not exceed $10 \%$ and rarely reached $20 \%$. Furthermore, for most raters, the highest values of absolute errors occurred for severity levels ranging from $50 \%$ to $70 \%$ and the two highest values were obtained in the evaluations made by raters 4 and 5 . All these results are indicative of a good precision level of the assessments using the diagrammatic scale elaborated for wheat blast in spikes. This statement is based on criteria already used to classify the results obtained by different authors in training procedures for evaluators to estimate
Figure 3. Absolute errors (actual severity - estimated severity) for assessments of blast, caused by Magnaporthe oryzae, on wheat spikes with the aid of the diagrammatic scale. Value of zero for absolute errors represents the ideal situation, in which estimated severity is equal to actual severity. 
disease severity using computer programs. In this sense, the computer programs Distrain and Disease.Pro, developed by Tomerlin \& Howell (24) and Nutter Jr. \& Worawitlikit (17) to quantify the disease severity levels on leaves of cereals and groundnuts, respectively, classified as excellent raters those whose errors did not exceed $5 \%$ and as good raters, those whose errors were less than $10 \%$. Stonehouse (23) also mentioned that the presence of some level of absolute error in the measurements can be compensated for by some advantages provided by the diagrammatic scale such as rapidity and standardization.

The scale presented in this study is expected to be used by a large number of students, technicians and researchers in Brazil and even abroad, in countries where wheat blast naturally occurs like Bolivia and Paraguay. There is a perception that the demand for tools that help evaluate and quantify this disease occurring on spikes is significant. In addition, it is important to emphasize that wheat blast has assumed a very large scale in terms of occurrence and damage to the wheat crops and is currently considered one of the major limiting factors to the expansion of wheat cultivation in the Brazilian Cerrado.

\section{ACKNOWLEDGMENTS}

The authors thank the financial support by Embrapa-Monsanto's Project (SEG 02.11.04.006.00.00).

\section{REFERENCES}

1. Amorim, L. Avaliação de Doenças. In: Bergamin Filho, A.; Kimati, H.; Amorim, L.; (Ed.). Vol.1. Manual de fitopatologia: princípios e conceitos. 3.ed., São Paulo: Ceres, 1995. v.1, p.647-671.

2. Amorim, L.; Bergamin Filho, A.; Palazzo, D.; Bassanezi, R.B.; Godoy, C.V.; Torres, G.A.M. Clorose variegada dos citros: uma escala diagramática para avaliação da severidade da doença. Fitopatologia Brasileira, Brasília, v.18, n.2., p.174-180,1993.

3. Bergamin Filho, A.; Amorim, L. Doenças de plantas tropicais: epidemiologia e controle econômico. Piracicaba. Agronômica Ceres, 1996. 299p.

4. Berger, R.D. Measuring disease intensity. In: Teng, P.S.; Krupa, S.V. (Ed.). Crop loss assessment which constrain production and crop improvement in agriculture and forestry. St. Paul: University of Minnesota, 1980. p.28-31.

5. Duveiller, E.; Hodson, D.; Tiedemann, A.V. Wheat blast caused by Maganaporthe grisea: a reality and new challenge for wheat research. In: International Wheat Conference, 8. 2010, St. Petersburg. Abstracts. St. Petersburg: Vavilov Research Institute of Plant Industry, 2010. p. 247-248.

6. Cruz, M.F.A.; Maciel, J.L.N.; Prestes, A.M.; Bombonatto, E.A.S.; Pereira, J.F.; Consoli, L. Caracterização genética e fenotípica de isolados de Pyricularia grisea do trigo. Tropical Plant Pathology, Brasília, v.34, n.6, p.393-401, 2009.

7. Cruz, M.F.A.; Prestes, A.M.; Maciel, J.L.N.; Scheeren, P.L. Resistência parcial à brusone de genótipos de trigo comum e sintético nos estádios de planta jovem e de planta adulta. Tropical Plant Pathology, Brasília, v.35, n.1, p.24-31, 2010.
8. Eyal, Z.; Brown, M.B. A quantitative method for estimating density of Septoria tritici pycnidia on wheat leaves. Phytopathology, St. Paul, v.66, n.1, p.11-14, 1976.

9. Horsfall, J.C.; Barrat, R.W. An improved grading system for measuring plant diseases. Phytopathology, St. Paul, v.35, n.8, p.665, 1945. (Abstract).

10. Igarashi, S.; Utiamada, C.M.; Igarashi, L.C.; Kazuma, A.H.; Lopes, R.S. Ocorrência de Pyricularia sp. em trigo no estado do Paraná. In: Reunião Nacional de Pesquisa de Trigo, 14., 1986, Londrina, Resumos. Londrina: IAPAR, 1986. p.57.

11. Lamari, L., Bernier, C.C. Evalution of wheat lines and cultivars to tan spot (Pyrenophora tritici-repentis) based on lesion type. Canadian Journal of Plant Pathology, Otawa, v.11, n.1, p.49$56,1989$.

12. Kohli, M.M.; Mehta, Y.R.; Guzman, E.; Viedma, L.; Cubilla, L.E. Pyricularia blast - a threat to wheat cultivation. In: International Wheat Conference, 8. 2010, St. Petersburg. Abstracts. St. Petersburg: Vavilov Research Institute of Plant Industry 2010 , p. 273 .

13. Maciel, J.L.N. Magnaporthe oryzae, the blast pathogen: current status and options for its control. CABI Reviews - Perspectives in Agriculture, Veterinary Science, Nutrition and Natural Resources, Oxfordshire, v.6, n.50, p.1-8, 2011.

14. Martins, M.C.; Guerzoni, R.A.; Câmara, G.M.S.; Mattiazzi, P.; Lourenço, S.A.; Amorim, L. Escala diagramática para a quantificação do complexo de doenças foliares de final de ciclo em soja. Fitopatologia Brasileira, Brasília, v.29, n.2, p.179-184, 2004.

15. Nutter JR, F.W.; Gleason, M.L.; Jenco, J.H.; Christians, N.C. Assessing the accuracy, intra-rater repeatability, and inter-rater reliability of disease assessment systems. Phytopathology, St. Paul, v. 83, n.8, p.806-812, 1993.

16. Nutter JR, F.W.; Schultz, P.M. Improving the accuracy and precision of disease assessments: selection of methods and use of computer-aided training programs. Canadian Journal of Plant Pathology, Otawa, v.17, n.2, p.174-184, 1995.

17. Nutter JR, F.W.; Worawitlikit, O. Disease.Pro: a computer program for evaluating and improving a person ability to assess disease proportion. Phytopathology, St. Paul, v.79, n.10, p.1135, 1989.

18. Peterson, R.F.; Campbell, A.B.; Hannah, A.E. A diagrammatic scale for estimating rust intensity on leaves and stems of cereals. Canadian Journal of Research, Ottawa, v.26, n.5, p.496$500,1948$.

19. Saari, E.E.; Prescott, J.M. A scale for appraising the foliar intensity of wheat diseases. Plant Disease Reporter, Beltsville, v.59, n.5, p.377-380, 1975 .

20. Schneider, C.A.; Rasband, W.S.; Eliceiri, K.W. NIH Image to Image J: 25 years of image analysis. Nature Methods, London, v.9, n.7, p.671-675, 2012.

21. Schramm, W.; Fulco, W.S.; Soares, M.H.G.; Almeida, A.M.P. Resistência de cultivares de trigo em experimentos ou cultivo no Rio Grande do Sul, às principais doenças fúngicas. Agronomia Sul-Riograndense, Porto Alegre, v.10, n.1, p.31-39, 1974.

22. Stack, R.W.; McMullen, M.P. A visual scale to estimate severity of fusarium head blight in wheat. Fargo: North Dakota State University, Extension Publication, 1995. p.1095.

23. Stonehouse, J. Assessment of Andean bean diseases using visual keys. Plant Pathology, London, v. 43, n.3, p.519-527, 1994.

24. Tomerlin, J.R.; Howell, T.A. Distrain: a computer program for training people to estimate disease severity on cereal leaves. Plant Disease, St. Paul, v.72, n.5, p.455-459, 1988. 